\title{
PENERAPAN MODEL LEARNING CYCLE 7E MAHASISWA PADA POKOK BAHASAN APLIKASI FUNGSI LINIER DALAM EKONOMI
}

\author{
Ninik Mutianingsih \\ Pendidikan Matematika, FKIP, Universitas PGRI Adi Buana Surabaya \\ ninikmutia@unipasby.ac.id
}

\begin{abstract}
Abstrak
Tujuan penelitian untuk mendeskripsikan hasil belajar mahasiswa dengan menerapkan model Learning Cycle $7 E$ dengan melakukan observasi pada proses pembelajaran. Pada hasil belajar mahasiswa dinilai dengan 2 ranah, yaitu ranah kognitif dan afektif. Learning Cycle 7E terdiri dari tujuh tahapan belajar yaitu: elicit (mendatangkan pengetahuan awal peserta didik), engage (membangkitkan minat), explore (mengeksplor), explain (menjelaskan), elaborate (menerapkan), evaluate (mengevaluasi), dan extend (memperluas). Penelitian ini merupakan penelitian deskriptif kuantitatif. Teknik yang digunakan dalam penelitian ini adalah tes. Berdasarkan hasil penelitian diperoleh pada ranah kognitif masih belum mencapai ketuntasan klasikal, karena karena dari jumlah 34 mahasiswa hanya 22 mahasiswa yang mencapai ketuntasan klasikal dengan presentase 64\%. Sedangkan untuk ranah afektif mencapai pada kriteria baik, kjarena pada pertemuan satu dan dua kriteria paling dominan adalah kriteria baik.
\end{abstract}

Kata kunci: model pembelajaran, learning cycle $7 E$

\section{Abstract}

Research aims to describe students learning outcomes by applying Learning Cycle 7E models by observing the learning process. In the student learning results are assessed with two domains, namely cognitive and affective realm. Learning Cycle $7 \mathrm{E}$ consists of seven learning phases: elicit (bring early learners knowledge), engage (generate interest), explore, explain (explain), elaborate (implement), evaluate (evaluate), and extend ( expand). This research is a quantitative descriptive study. The technique used in this research is the test. Based on the results of research obtained in the realm of cognitive still has not reached the classical, because because of the number of 34 students only 22 students who reached the classical tunic with a percentage of $64 \%$. As for the affective realm of achieving the good criteria, the meeting of the one and two most dominant criteria is good criteria.

Keywords: learning model, learning cycle $7 \mathrm{E}$

\section{PENDAHULUAN}

Proses pembelajaran merupakan proses yang didalamnya terdapat interaksi dan komunikasi antara pendidik dan peserta didik yang berlangsung untuk mencapai tujuan belajar (Rustaman, 2001). Pada proses pembelajaran pendidik dan peserta didik merupakan dua komponen yang tidak dapat dipisahkan dan harus terjalin interaksi yang saling menunjang agar hasil belajar dapat tercapai secara maksimal.

Dalam proses pembelajaran selama ini, pada umumnya guru senantiasa mendominasi kegiatan dan segala inisiatif datang dari guru, sementara peserta didik sebagai obyek untuk menerima apa yang dianggap penting dan menghafal materi yang di sampaikan oleh guru serta tidak berani mengeluarkan ide-ide pada saat pembelajaran berlangsung. Hal ini dapat dikatakan bahwa guru dalam kegiatan belajar mengajar di kelas kurang menekankan pada aspek kemampuan peserta didik untuk aktif dalam pembelajaran matematika.

Paradigma pendidikan yang mulai mengalai pergeseran. Peristiwa belajar saat ini didasarkan pada konsep stimulus-respon mulai berganti menjadi pendekatan yang lebih manusiawi. Suatu pendekatan yang lebih menekankan pada hakikat manusia sebagai

makhluk pembangun ilmu pengetahuan. Hal ini ini dikenal sebagai pendekatan konstruktivisme. Pendekatan yang dimana seorang guru bukan sebagai sumber pengetahuan, melainkan sebagai fasilitator dalam proses pembelajaran dan murid bukan sebagai objek tetapi sebagai subjek (pelaku).

Supaya dalam proses belajar matematika lebih bermakna, makaa peerta didik harus mempunyai aspek psikomotorik untuk menemukan ide dan terbentuk sebuah 
konsep, sehingga matematika tidak lagi merukana konsep yang abstrak yang hanya menghafal rumus-rumus. Sehingga diharapkan kegiatan belajar mengajar yang dilakukan berpusat pada peserta didik serta dapat meningkatkan hasil belajar yang mencakup peningkatan aspek kognitif, afektif, dan psikomotorik (Fatonah, 2005).

Agar tujuan tersebut terwujud, pastinya dibutuhkan suatu proses pembelajaran yang sesuai. Seteleh peserta didik melalui proses tersebut maka peserta didik akan dinilai dari hasil belajar yang telah dijalani. Ketika berbicara tentang proses belajar tentunya tidak terlepas dari model pembelajaran, model pembelajaran yang diterapkan adalah model pembelajaran learning cycle 7E.

Model pembelajaran learning cycle 7E merupakan salah satu model pembelajaran dengan pendekatan konstruktivis. Model pembelajaran ini merupakan model pembelajaran penyempurnaan dari model learning cycle 5E. Learning cycle dikembangkan menjadi tujuh tahapan. Perubahan yang terjadi pada tahapan siklus belajar 5E menjadi $7 \mathrm{E}$ yaitu terjadi pada fase engage menjadi dua tahapan yaitu elicit dan engage, sedangkan untuk tahap elaborate dan evaluate menjadi tiga tahapan yaitu elaborate, evaluate, dan extend (Eisenkraft, 2003).

Tahap-tahap model pembelajaram learning cycle $7 \mathrm{E}$ (Arthur, 2003) yaitu 1) elicit (mendatangkan pengetahuan awal peserta didik), 2) engagement (membangkitkan minat), 3) exploration (mengeksplor), 4) explaination (menjelaskan), 5) elaboration (menerapkan), 6) evaluation (mengevaluasi), 7) extand (memperluas).

Penelitian tentang penerapan model learning cycle 7E telah dilakukan oleh beberapa peneliti. Ariyanto (2012) meneliti tentang efektifitas pembelajaran matematika model learning cycle $5 \mathrm{E}$ berbantuan $\mathrm{CD}$ interaktif materi segitiga kelas VII di SMPN 2 Limpung Kabupaten Batang. Pengaruh model pembelajaran learning cycle 7E terhadap hasil belajar fisika siswa SMA, oleh Imaniyah, siswoyo, dan Bakri (2015). Laelasari. subroto dan Nurul (2015) meneliti tentang penerapan model pembelajaran learning cycle 7E dalam kemampuan representasi matematis mahasiswa. Oleh Susanti, Prihatnani, dan Ratu (2016) meneliti tentang pengaruh pembelajaran learning cycle 7E terhadap kemampuan pemecahan masalah matematika bagi siswa kelas X MIA SMA Kristen Satya Wacana Salatiga.

Novitasari, Suherman, dan Mirna (2014) tentang pengaruh model pembelajaran learning cycle terhadap pemahaman konseo matematika siswa kelas X SMA Negeri 15 Padang Tahun Pelajaran 2013/2014. Partini, Budijanto, dan Bachri (2017) tentang penerapan model pembelajaran learning cycle $7 \mathrm{E}$ untuk meningkatkan kemampuan berpikir kritis siswa. Hardiansyah, Waslaluddin, dan Rusnayati (2013) meneliti tentang penerapan model pembelajaran learning cycle $7 \mathrm{E}$ untuk meningkatkan keterampilan berpikir ritis dan penguasaan konsep siswa SMA. Berdasarkan beberapa penelitian yang diungkapkan di atas, belum ada penelitian yang membahas tentang penerapan model learning cycle $7 \mathrm{E}$ mahasiswa khususnya pada pokok bahasan aplikasi fungsi linier dalam ekonomi.

Berdasarkan uraian di atas, penelitian ini dapat diketahui bahwa pentingnya model pembelajaran dalam proses pembelajaran, sehingga tujuan penelitian ini adalah mendeskripsikan hasil belajar mahasiswa setelah penerapan model learning cycle 7E.

\section{METODE}

Penelitian ini merupakan penelitian deskriptif kuantitatif. Penelitian deskriptif kuantitatif dengan cara mencari informasi tentang gejala yang ada, didefinisikan dengan jelas tujuan yang akan dicapai, merencanakan cara pendekatannya, mengumpulkan data sebagian bahan untuk membuat laporan.

Penelitian ini dilakukan dengan menerapkan model learning cycle 7E, dengan melakukan observasi pada proses pembelajaran. Pada hasil belajar mahasiswa dinilai dengan 2 ranah, yaitu ranah kognitif dan afektif.

Sumber data dalam penelitian ini adalah mahasiswa Pendidikan Matematika Universitas PGRI Adi buana Surabaya yang sedang mengampu mata kuliah Matematika Kejuruan. Mahasiswa tersebut saat ini berada pada semester 7 dan bukan mahasiswa transfer ataupun mahasiswa recourse.

Teknik pengumpulan data yang dilakukan tes dimana tes merupakan kumpulan pertanyaan yang digunakan untuk mengetahui keterampilan, kemampuan, pengetahuan yang dimiliki oleh individu maupun kelompok. Tujuan pemberian tes adalah untuk mengecek pemahaman terhadao pmbelajaran yang tekah di ikuti selama pembelajatran berlangsung. selain itu juga digunakan untuk mengetahui hasil beljar mahasiswa.

Teknik analisis data yang digunakan dalam peneilitian ini adalah data hasil belajar peserta didik digunakan untuk mendeskripsikan hasil belajar peserta didik selama proses pembelajaran berlangsung dengan menerapkan model learning cycle 7e dan berpedoman kepada tiga ranah aspek, yaitu aspek kognitif, afektif, dan psikomotorik.

a. Hasil Belajar Kognitif

Untuk menganalisis data kognitif peserta didik digunakan acuan kriteria, yaitu peserta didik dikatakan tuntas dalam tes akhir materi himpunan. Ketuntasan hasil belajar klasikal dihitung dengan rumus :

$$
\text { Nilai }=\frac{\text { shor yang diperoleh }}{\text { skor maksimal }} \times 100
$$

Setelah dianalisis, data tes hasil belajar disajikan dalam bentuk tabel dan dideskripsikan. 
b. Hasil Belajar Afektif

Untuk menganalisis data afektif peserta didik, setiap indikator memiliki skala penilaian antara 1 sampai 4 sesuai dengan skala penilaian sikap, maka menggunakan rumus sebagai berikut :

$$
\text { Nilai }=\frac{\text { skor yang diperoleh }}{\text { skor maksimal }} \times 4
$$

Sedangkan untuk mengetahui nilai afektif pesertadidik, dapat dilihat pada tabel berikut.

Tabel 1. Acuan Kriterian Ketuntasan Belajar

\begin{tabular}{|c|c|c|c|}
\hline \multirow{2}{*}{ Predikat } & \multicolumn{2}{|c|}{ Nilai Kompetensi } & \multirow{2}{*}{ Sikap } \\
\cline { 2 - 3 } & Pengetahuan & Ketrampilan & \\
\hline A & 4 & 4 & \multirow{2}{*}{ SB } \\
\hline A- & 3,66 & 3,66 & \\
\hline B+ & 3,33 & 3,33 & \multirow{2}{*}{ B } \\
\hline B & 3 & 3 & \\
\hline B- & 2,66 & 2,66 & \\
\hline C+ & 2,33 & 2,33 & \multirow{2}{*}{ C } \\
\hline C & 2 & 2 & \\
\hline C- & 1,66 & 1,66 & \multirow{2}{*}{ K } \\
\hline D+ & 1,33 & 1,33 & \\
\hline D & 1 & 1 & \\
\hline
\end{tabular}

Keterangan :

$\begin{array}{ll}\mathrm{SB} & =\text { Sangat Baik } \\ \mathrm{B} & =\text { Baik } \\ \mathrm{C} & =\text { Cukup } \\ \mathrm{K} & =\text { Kurang }\end{array}$

\section{HASIL DAN PEMBAHASAN}

\section{Hasil Penelitian}

Penelitian yang dilakukan adalah penerapan model learning cycle $7 E$ pada pokok bahasan aplikasi fungsi linier dalam ekonomi pada mahasiswa pendidikan matematika yang sedang mengampu mata kuliah matematika kejuruan. Pada hasil penelitian dan pembahasan ini akan dijelaskan tentang hasil belajar mahasiswa dalam tiga aspoek yaitu aspek konitif dan afektif setelah proses pembelajaran dan penerapan model pembelajaran learning cycle $7 E$.

\section{a. Ranah kognitif}

Untuk menganalisis data hasil belajar digunakan acuan kriteria yaitu peserta didik dikatakan tuntas dalam tes akhir aplikasi fungsi linier dalam ekonomi yang dianalisis dengan menggunakan acuan kriteria yang telah ditetapkan yaitu mahasiswa dikatakan tuntas belajar jika hasil belajar atau tes yang diperoleh $\geq 80$. Data tes hasil belajar dapat dilihat pada tabel 2, berikut:

Tabel 2. Tes hasil belajar mahasiswa untuk ranah kognitif.

\begin{tabular}{|c|c|c|c|}
\hline No. & Nama & Nilai & Keterangan \\
\hline 1 & A RZ & 20 & Tidak Tuntas \\
\hline
\end{tabular}

\begin{tabular}{|c|c|c|c|}
\hline No. & Nama & Nilai & Keterangan \\
\hline 2 & ATP & 88 & Tuntas \\
\hline 3 & AACW & 86 & Tuntas \\
\hline 4 & $\mathrm{AS}$ & 100 & Tuntas \\
\hline 5 & AJP & 78 & Tidak Tuntas \\
\hline 6 & APY & 80 & Tuntas \\
\hline 7 & BHB & 56 & Tidak Tuntas \\
\hline 8 & CSMP & 90 & Tuntas \\
\hline 9 & DAW & 40 & Tidak Tuntas \\
\hline 10 & FPA & 88 & Tuntas \\
\hline 11 & FKP & 80 & Tuntas \\
\hline 12 & HPL & 82 & Tuntas \\
\hline 13 & IJT & 85 & Tuntas \\
\hline 14 & $\mathrm{KF}$ & 87 & Tuntas \\
\hline 15 & LK & 89 & Tuntas \\
\hline 16 & MIYP & 42 & Tidak Tuntas \\
\hline 17 & MGPA & 89 & Tuntas \\
\hline 18 & MSA & 72 & Tidak Tuntas \\
\hline 19 & MRJK & 65 & Tidak Tuntas \\
\hline 20 & MIF & 85 & Tuntas \\
\hline 23 & MRAS & 74 & Tidak Tuntas \\
\hline 22 & $\mathrm{ND}$ & 85 & Tuntas \\
\hline 23 & NRF & 92 & Tuntas \\
\hline 24 & $\mathrm{NCP}$ & 85 & Tuntas \\
\hline 25 & NF & 82 & Tuntas \\
\hline 26 & PCR & 90 & Tuntas \\
\hline 27 & REPP & 84 & Tuntas \\
\hline 28 & RBR & 50 & Tidak Tuntas \\
\hline 29 & SNMW & 82 & Tuntas \\
\hline 30 & SZA & 76 & Tidak Tuntas \\
\hline 31 & SPP & 100 & Tuntas \\
\hline 32 & VAA & 40 & Tidak Tuntas \\
\hline 33 & $\mathrm{YP}$ & 90 & Tuntas \\
\hline 34 & ZAN & 65 & Tidak Tuntas \\
\hline
\end{tabular}

Pada tabel 2 terlihat bahwa, tes hasil belajar peserta didik untuk ranah kognitif dari 34 peserta didik jumlah mahasiswa yang mendapat nilai $\geq 80$ sebanyak 22 mahasiswa sehingga dikatakan tuntas. Sedangkan yang mendapatkan nilai $\leq 80$ sebanyak 12 peserta didik, sehingga dikatakan tidak tuntas.

\section{b. Ranah afektif}

Analisis hasil belajar untuk afektif mahasiswa menggunakan acuan kriteria penilaian pada tabel 1, yaitu penilaian afektif mahasiswa terbagi menjadi empat kriteria diantaranya adalah SB (sangat baik), B (baik), C (cukup), dan $\mathrm{K}$ (kurang). Hasil analisis hasil belajar ranah afektif mahasiswa dapat dilihat pada tabel berikut:

Tabel 3. Tes hasil belajar mahasiswa ranah afektif

\begin{tabular}{|c|c|c|c|c|c|}
\hline \multirow{2}{*}{ No. } & \multirow{2}{*}{ Nama } & \multicolumn{2}{|c|}{ Pertemuan 1 } & \multicolumn{2}{c|}{ Pertemuan 2 } \\
\cline { 3 - 6 } & & Skor & Nilai & Skor & Nilai \\
\hline 1 & A RZ & 2.38 & C & 3.25 & B23 \\
\hline 2 & ATP & 3.25 & B & 3.88 & SB \\
\hline 3 & AACW & 2.75 & B & 3.13 & B \\
\hline 4 & AS & 3.75 & SB & 3.88 & SB \\
\hline 5 & AJP & 2.63 & C & 3.38 & B \\
\hline
\end{tabular}




\begin{tabular}{|c|c|c|c|c|c|}
\hline \multirow{2}{*}{ No. } & \multirow{2}{*}{ Nama } & \multicolumn{2}{|c|}{ Pertemuan 1 } & \multicolumn{2}{c|}{ Pertemuan 2 } \\
\cline { 3 - 6 } & & Skor & Nilai & Skor & Nilai \\
\hline 6 & APY & 3.13 & B & 3.75 & SB \\
\hline 7 & BHB & 2.13 & C & 3.38 & B \\
\hline 8 & CSMP & 3.00 & B & 3.88 & SB \\
\hline 9 & DAW & 2.50 & C & 2.88 & B \\
\hline 10 & FPA & 3.13 & B & 3.00 & B \\
\hline 11 & FKP & 2.50 & C & 3.50 & B \\
\hline 12 & HPL & 2.25 & C & 3.75 & SB \\
\hline 13 & IJT & 2.88 & B & 3.25 & B \\
\hline 14 & KF & 3.13 & B & 3.75 & SB \\
\hline 15 & LK & 2.75 & B & 2.88 & B \\
\hline 16 & MIYP & 3.00 & B & 3.25 & B \\
\hline 17 & MGPA & 3.00 & B & 3.25 & B \\
\hline 18 & MSA & 2.38 & C & 3.00 & B \\
\hline 19 & MRJK & 2.63 & C & 2.88 & B \\
\hline 20 & MIF & 3.25 & B & 3.63 & B \\
\hline 21 & MRAS & 2.88 & B & 3.25 & B \\
\hline 22 & ND & 3.25 & B & 3.75 & SB \\
\hline 23 & NRF & 3.13 & B & 3.75 & SB \\
\hline 24 & NCP & 3.13 & B & 3.50 & B \\
\hline 25 & NF & 2.88 & B & 3.25 & B \\
\hline 26 & PCR & 3.38 & B & 3.88 & SB \\
\hline 27 & REPP & 3.00 & B & 3.25 & B \\
\hline 28 & RBR & 2.50 & C & 3.00 & B \\
\hline 29 & SNMW & 3.00 & B & 3.13 & B \\
\hline 30 & SZA & 2.88 & B & 3.00 & B \\
\hline 31 & SPP & 3.25 & B & 3.75 & SB \\
\hline 32 & VAA & 2.50 & C & 3.25 & B \\
\hline 33 & YP & 3.25 & B & 3.75 & SB \\
\hline 34 & ZAN & 2.50 & C & 3.00 & B \\
\hline
\end{tabular}

Dari tabel 3 terlihat bahwa, hasil penelitian afektif mahasiswa pada pertemuan 1, dari jumlah 34 mahasiswa 1 mahasiswa mendapat nilai SB (sangat baik) sebanyak 22 mahasiswa yang mendapat nilai B (baik), sebanyak 11 mahasiswa yang mendapat nilai C (cukup). Pada pertemuan 2, dari jumlah 34 mahasiswa sebanyak 11 mahasiswa yang mendapat nilai SB (sangat baik), sebanyak 23 mahasiswa yang mendapat nilai B (baik).

\section{Pembahasan}

Pada ranah kognitif, berdasarkan hasil tes yang sudah diperoleh pada mahasiswa setelah 2 kali pertemuan dengan penerapan model learning cycle $7 E$, dapat dilihat bahwa dari 34 mahasiswa jumlah mahasiswa yang mendapat nilai $\geq 80$ sebanyak 22 mahasiswa dengan presentase $64 \%$ sehingga dikatakan tiuntas, sedangkan 12 mahasiswa mendapat dengan presentase $36 \%$ nilai $\leq 80$ dikatan belum tuntas. Berdasarkan hasil analisis tes hasil belajar setelah mengikuti pembel;ajaran dengan peneraspan model learning cycle $7 E$, hasil belajar pada ranah kognitif belum mencapai ketuntasan klasikal, karena dari jumlah 34 mahasiswa hanya 22 mahasiswa yang mencapai ketuntasan klasikal dengan presentase $64 \%$.

Pada ranah afektif, berdasarkan hasil tes yang sudah diperoleh dari 34 mahsiswa pada pertemuan pertama terdapat 1 mahasiswa dengan penilaian afektifnya sangat baik, ini bearti mahasiswa tersebut sangat memperhatikan dan mendengarkan dosen pada saat proses pembelajaran, sebanyak 22 mahasiswa mendapat penilaian baik, yang artinya 22 mahasiswa dalam satu kelas mencapi sikap baik selama penerapan model learning cycle $7 E$. Terlihat bahwa selama proses pembelajran m,ahasiswa memunculkan sikap rasa ingin tahu dengan bertanya pasa dosen dan teman yang menyajikan materi di depan kelas. Selain itu, selama proses pembelajaran mahsiswa juga memunculkan sikap percaya diri dengan mengerjakan soal didepan kelas dan menjelaskan hasil kerjaannya. Sedangan terdapat 11 mahasiswa mendapat nilai cukup, hal ini berarti mahasiswa tidak begitu memunculkan sikap rasa ingin tahu seperti bersikap pasif selama proses pembelajaran.

Pada pertemuan kedua, sebanyak 11 mahasiswa mendapat nilai afektif sangat baik, terlihat bahwa dari 8 indikator sikap, mahasiswa tersebut memunculkan sikap lebih aktif, seperti rasa ingin tahu, tanggungjawab, dan sikap percaya diri yang tinggi dan konsisten.

Dari hasil penjelasan di atas, dapat disimpulkan bahwa hasil belajar dalam penilaian afektif selama dua kali pertemuan pada penerapan model learning cycle $7 E$ mencapai pada kriteria baik, karena pada pertemuan satu dan dua kriteria paling dominan adalah kriteria baik.

\section{PENUTUP}

\section{Simpulan}

Berdasarkan hasil dan pembahasan di atas, dapat disimpulkan bahwa tes hasil belajar mahasiswa pada ranah kognitif masih belum mencapai ketuntasan klasikal, karena karena dari jumlah 34 mahasiswa hanya 22 mahasiswa yang mencapai ketuntasan klasikal dengan presentase $64 \%$. Sedangkan untuk ranah afektif mencapai pada kriteria baik, kjarena pada pertemuan satu dan dua kriteria paling dominan adalah kriteria baik.

\section{Saran}

Penelitian ini bisa digunakan untuk pengembangan penelitian selanjutnya.

\section{DAFTAR PUSTAKA}

Ariyanto, L. (2012). Efektitas pembelajaran matematika model learning cycle 5e berbantun cd interaktif matematika segitiga. IKIP PGRI semarang , 2072015.

Arthur, E. 2003. Expanding the 5E Model. A Journal for High School Science Educators Published by The National Science Teachers Association The Science Teacher, 1-4.

Eisenkraft, A. 2003. Expanding the 5E model: A proposed 7E model emphasizes "transfer of learning" and the importance of eliciting prior understanding. [Teacher Practitioner]. The Science Teacher, 70, 5659.

Imaniyah, I., Siswoyo, \& Bakri, F. (2015). Pengaruh model pembelajaran learning cycle 7E terhadap hasil belajar fisika siswa SMA. JPPPF jurnal penelitian \& pengembangan pendidikan fisika, 17-14. 
Laelasari., Subroto, T., \& Nurul, I. K. 2015. Penerapan Model Pembelajaran Learning Cycle $7 E$ dalam Kemampuan Representasi Matematis Mahasiswa. Journal Euclid, ISSN 2355-1712, vol. 1, No. 2, pp. 60-136.

Novitasari, W., Suherman, \& Mirna. 2014. Pengaruh model pembelajaran learning cycle terhadap pemahaman konsep. Jurnal pendidikan matematika , 60-64.

Fatonah, S. 2005. Aplikasi aspek kognitif (teori bloom). Kaunia, 151-167.

Hardiansyah, D., Waslaluddin., \& Rusnayati, H. 2013. Penerapan Model Pembelajaran Learning Cycle $7 E$ untuk Meningkatkan Keterampilan Berpikir Kritis dan Penguasaan Konsep Siswa SMA.

Hosnan, M. 2014. Pendekatan Saintifik dan Kontekstual dalam Pembelajaran Abad 21. Bogor: Ghalia Indonesia.

Rustaman. 2001. "Keterampilan Bertanya dalam Pembelajaran IPA. "dalam Handout Bahan Pelantikan Guru-Guru IPA SLTP Se-Kota Bandung di PPG IPA. Jakarta: Depdiknas.

Partini., Budijanto,. \& Bachri, S. 2017. Penerapan Model Pembelajaran Learning Cycle 7E untuk Meningkatkan Kemampuan Berpikir Kritis Siswa. Jurnal Pendidikan: Teori, Penelitian, dan Pengembangan, Volume: 2, Nomor: 2, Bulan Februari Tahun 2017, halaman: 268-272. 
Ninik Mutianingsih: Penerapan Model Learning Cycles 7E Mahasiswa pada Pokok Bahasan Aplikasi Fungsi Linier dalam Ekonomi 